Journal of Engineering and Applied Sciences 14 (7): 2187-2194, 2019

ISSN: 1816-949X

(C) Medwell Journals, 2019

\title{
The Boiler Pipes Failure in Power Plants (South of Baghdad Station)
}

\author{
${ }^{1,2}$ Ahmed A. Fadhil, ${ }^{2}$ Muataz H. Ismael, ${ }^{2}$ Adiba A. Mahmmod, ${ }^{2}$ Omar A. Imran, \\ ${ }^{2}$ Salah N. Farhan and ${ }^{1}$ Hongfang Liu \\ ${ }^{1}$ Key laboratory of Material Chemistry for Energy Conversion and \\ Storage (Ministry of Education), Hubei Key Laboratory of Material and Service Failure, \\ School of Chemistry and Chemical Engineering, \\ Huazhong University of Science and Technology (HUST), 1037 Luoyu Road, \\ 430074 Wuhan, PR China \\ ${ }^{2}$ Department of Chemical Engineering, College of Engineering, University of Diyala, \\ Baquba City 32001, Diyala Governorate, Iraq
}

\begin{abstract}
Pipes boilers in power plants leads to big problems and loss of thermal equipment. Through the field visit to South Baghdad station for electrical power been getting several problems faced by pipes boilers in the plant. The current study aims to analyze the main causes that lead to the failure of the pipes boilers in South Baghdad electric power. Failure analysis methods including chemical, mechanical characterizations and visual examination using optical microscopy in combination using Scanning Electron Microscopy (SEM) equipped. The results of this research indicate that the main reason behind for this failure tow type of failure first one the Glue remnants of heavy fuel combustion (Ash) on the outside of the pipes boilers. By examining The chemical composition of fuel ash is $69 \%$ Vanadium Oxide $\left(\mathrm{V}_{2} \mathrm{O}_{5}\right)$ and $31 \%$ Sodium Sulfate $\left(\mathrm{Na}_{2} \mathrm{SO}_{4}\right)$. These materials are of relatively low melting point between $(550-560)^{\circ} \mathrm{C}$ and the working conditions of these boilers are between $(500-800)^{\circ} \mathrm{C}$. The second one flow water inside the pipes boiler contains a high present of the primary ions distinguished were Bicarbonate proportion $\left(\mathrm{HCO}^{3-}\right)$ Chloride $\left(\mathrm{Cl}^{-}\right)$and Sulfate $\left(\mathrm{SO}_{4}{ }^{2-}\right)$ where Chloride $(\mathrm{Cl})$ has been known as aggressive ions. The $\mathrm{pH}$ of water was equal to 8.2 or unnecessary condition.
\end{abstract}

Key words: Hot corrosion, high temperatures, carbon steel, boiler, fuel ash, several problems

\section{INTRODUCTION}

Hot corrosion is one of the issues that undermine the turbines and steam boilers that work utilizing heavy fuel oil. These utensils can be worked at high pressure and temperatures. Because of the ignition of fuel oil inside the boilers produces fiery debris, these squanders $(550-565)^{\circ} \mathrm{C}$ assaulting the surface of the tube prompting broad kettle harm (Gouda et al., 1981). There are additionally a few elements that influence the corrosion. The most imperative factors are the temperature, substance creation of the stresses and metal surface, contain a high extent of sodium sulfates $\left(\mathrm{Na}_{2} \mathrm{SO}_{4}\right)$ and Vanadium $\left(\mathrm{V}_{2} \mathrm{O}_{5}\right)$ with low melting points boilers play an important role in power plant sand yet are much more economical and efficient boilers in steam generation in power plants corrosion factors one of the reasons that cause failure in boiler units (Gouda et al., 1981; Rocca et al., 2003) Vanadium $\left(\mathrm{V}_{2} \mathrm{O}_{5}\right)$
Sodium Sulfate $\left(\mathrm{Na}_{2} \mathrm{SO}_{4}\right)$ salts Chloride $(\mathrm{Cl})$, Bicarbonate $\left(\mathrm{HCO}^{3 \cdot}\right)$ and Sulphate $\left(\mathrm{SO}_{4}{ }^{2-}\right)$ are the main causes of failure of boilers. Through the field visit to South Baghdad station to electrical power been getting several problems faced by pipes boilers in the plant. The current study aims to analyses the main cause that lead to the failure of the pipes boilers in South Baghdad electric power (Barbooti et al., 1988, 2012; Hancock, 1982). These materials are of relatively low melting point between $(550-560)^{\circ} \mathrm{C}$ and the working conditions of these boilers are between $(700-750)^{\circ} \mathrm{C}$ show in Fig. 1a (Rapp, 1990; Saji and Thoumas, 2007). Second one flow water inside the pipes boiler containing a high present of the main ions detected were bicarbonate, chloride and sulphate where chloride has be present known as aggressive ion. Water was identified to have $\mathrm{pH}$ of 8.2 or basic conditions show in Fig. 1b.

Corresponding Author: Hongfang Liu, Key laboratory of Material Chemistry for Energy Conversion and Storage (Ministry of Education), Hubei Key Laboratory of Material and Service Failure, School of Chemistry and Chemical Engineering, Huazhong University of Science and Technology (HUST), 1037 Luoyu Road, 430074 Wuhan, PR China 
Table 1: The operational conditions for boilers that operating in power station South of Baghdad

\begin{tabular}{ll}
\hline Specification and operating data & Values \\
\hline Temp & $(700-750)^{\circ} \mathrm{C}$ \\
Time of operating & $(20) \mathrm{h}$ \\
Fuel using for operating & Havey fuel oil (Kirkuk North of Iraq) \\
Pipes metals & Carbon steel \\
\hline
\end{tabular}

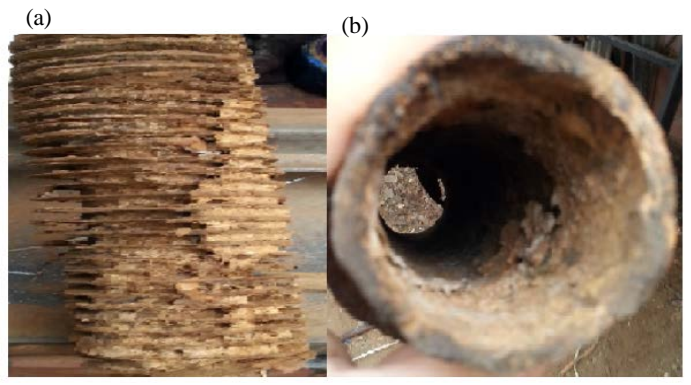

Fig. 1: a) Heavy fuel combustion residues sticking above the surface of the tube is the collateral damage caused waste and b) The internal corrosion product inside the tube

The accumulation of such remnants as well as the salts cause the failure of these pipes and pitting corrosion this failure is causing significant losses in power station South of Baghdad. Table 1 shows the operational conditions for these boilers.

\section{MATERIALS AND METHODS}

\section{Analytical techniques}

Visual examination: Figure 1a shows the corrosion in pipes boilers very clear also the fuel combustion residues sticking above the surface of the pipe and corrosion products. This west assaulting the surface of the tube prompting the result disintegration the metal (Rapp, 1990; Rhys-Jones et al., 1983; Hancock, 1968, 1982; Khadom et al., 2009; Young, 2008; Paul and Seeley, 1991; Srivastava et al., 1997; Saji and Thoumas, 2007). And in addition there are a factors that influence the conduct of corrosion one of the most important factors is the forces acting properties and the chemical composition of the metal surface temperature (Kolpakov et al., 2007; Voevodin et al., 2003; Rout et al., 2003; Laco et al., 2005). Either by the internal corrosion of the pipeline. It is clear shows in Fig. 1 b shows the west production inside the pipes of boilers result from the chloride ions through the flow of water inside the pipes water inside the pip containing a high present of the fundamental ions distinguished detected were Chloride $\left(\mathrm{Cl}^{-}\right)$, sulfate $\left(\mathrm{SO}_{4}{ }^{2-}\right)$ and Bicarbonate $\left(\mathrm{HCO}^{3-}\right)^{-}$where Chloride $\left(\mathrm{Cl}^{-}\right)$has been known as aggressive ions.
Table 2: The chemical composition (Wt.\%) of the testing samples

\begin{tabular}{llllllll}
\hline $\mathrm{S}$ & $\mathrm{Si}$ & $\mathrm{P}$ & $\mathrm{C}$ & $\mathrm{Mn}$ & $\mathrm{Cr}$ & $\mathrm{M}$ & $\mathrm{Fe}$ \\
\hline 0.06 & 0.5 & 0.007 & 0.066 & 0.18 & 1.9 & 0.53 & Remain \\
\hline
\end{tabular}

Table 3: The chemical composition of water

\begin{tabular}{lll}
\hline Parameter & Units & Values \\
\hline $\mathrm{pH}$ & - & 8.1 \\
Chloride $(\mathrm{Cl})$ & $\mathrm{ppm}$ & 5884 \\
Bicarbonate $\left(\mathrm{HCO}^{3-}\right)$ & $\mathrm{ppm}$ & 235 \\
Sulphate $\left(\mathrm{SO}_{4}^{2-}\right)$ & $\mathrm{ppm}$ & 202 \\
\hline
\end{tabular}

Table 4: Melting points of various compounds at high temperatures

\begin{tabular}{lc}
\hline Compound & Melting point $\left({ }^{\circ} \mathrm{C}\right)$ \\
\hline $5 \mathrm{NaO}_{2} \mathrm{~V}_{2} \mathrm{O}_{4}, 11 \mathrm{~V}_{2} \mathrm{O}_{5}$ & 540 \\
$\mathrm{NaO}, \mathrm{V}_{2} \mathrm{O}_{4} \cdot 5 \mathrm{~V}_{2} \mathrm{O}_{5}$ & 625 \\
$\mathrm{NaVO}_{3}$ & 630 \\
$\mathrm{~V}_{2} \mathrm{O}_{5}$ & 680 \\
$\mathrm{MgV}_{2} \mathrm{O}_{6}$ & 700 \\
$\mathrm{Al}_{2}\left(\mathrm{SO}_{4}\right)_{3}$ & 770 \\
$\mathrm{NaSO}_{4}$ & 885 \\
$\mathrm{FeVO}_{4}$ & 816 \\
$\mathrm{FeV}_{2} \mathrm{O}_{6}$ & 1000 \\
$\mathrm{Mg}_{3} \mathrm{~V}_{2} \mathrm{O}_{8}$ & 1120 \\
$\mathrm{MgSO}_{4}$ & 1124 \\
$\mathrm{MgO}$ & 2800 \\
$\mathrm{FeVO}_{3}$ & 1500 \\
$\mathrm{Fe}_{3} \mathrm{O}_{4}$ & 1565 \\
$\mathrm{CO}_{2} \mathrm{~V}_{2} \mathrm{O}_{7}$ & 820
\end{tabular}

Analysis of materials: Field observation and locally examination was carried out for pipes of steam boilers at South Baghdad electrical power generation station. Steel samples and fuel ash were collected from inside the boilers. Special alloy that made pipes of boiler is taken from inside the tubes of boiler which used in the South of Baghdad station for electric power generation. The chemical composition of samples is carbon steel is given in Table 1 this test by (XRD). Fuel ash taken from tube fireside. The chemical composition of fuel ash is $69 \%$ Vanadium Oxide $\left(\mathrm{V}_{2} \mathrm{O}_{5}\right)$ and $31 \%$ sodium sulfate $\left(\mathrm{Na}_{2} \mathrm{SO}_{4}\right)$. The chemical composition of the water phase present from Dijla river direct without any treatment selected by atomic adsorption method with the outcomes are given in Table 2-4.

Effect of fuel ash: Three elements of fuel, mainly responsible for deposits and corrosion (sulfur, vanadium and sodium) sulfur is the involved most frequently and major offender. Vanadium troublesome as it occurs appreciably only in same fuel oil. While sodium found more frequently in liquid fuels. Sulfur is common to fuel oil and compounds of sulfur with iron, oxygen and the alkalis are most offenders in the wastage of metals and frequently in the accumulation of deposits. It is helpful to discuss the parts of sulfur and sodium together, since, it is the compound $\left(\mathrm{Na}_{2} \mathrm{SO}_{4}\right)$ which required in the hot corrosion reaction. The sodium in the oil is principally present as $(\mathrm{NaCl})$ and is promptly vaporized amid the ignition procedure. There are various diverse systems by 
which vaporization can happen, yet once total most the sodium exist in the vapor stage either $(\mathrm{NaCl})$ or $(\mathrm{NaOH})$, their relative extents being dictated by the interaction of the sort:

$$
\mathrm{H}_{2} \mathrm{O}+\mathrm{NaCl}_{(\mathrm{g})} \leftrightarrow \mathrm{NaOH}_{(\mathrm{g})}+\mathrm{HCl}
$$

$\mathrm{SO}_{3}$ in the fuel gases will react with the $(\mathrm{NaOH})$ to form $\left(\mathrm{Na}_{2} \mathrm{SO}_{4}\right)$ which will condense as such (Eq. 2):

$$
2 \mathrm{NaOH}_{(\mathrm{g})}+\mathrm{SO}_{3} \leftrightarrow \mathrm{Na}_{2} \mathrm{SO}_{4}+\mathrm{H}_{2} \mathrm{O}
$$

Vanadium, sodium and sulfate react to from products at low temperature $\left(540^{\circ} \mathrm{C}\right)$ with a eutectic of $(35 \mathrm{~mole} \%$ $\left.\mathrm{Na}_{2} \mathrm{O}\right)$ molten at $\left(530^{\circ} \mathrm{C}\right)$. The low melting compounds are the most harmful corrosion in residual fuel. Investigations indicated that three compounds were formed by reaction of sodium sulfate and vanadium pent oxide (Eq. 3-5):

$$
\begin{gathered}
\mathrm{Na}_{2} \mathrm{SO}_{4}+\mathrm{V}_{2} \mathrm{O}_{5} \rightarrow 2 \mathrm{NaVO}_{3}+\mathrm{SO}_{3} \\
\mathrm{Na}_{2} \mathrm{SO}_{4}+3 \mathrm{~V}_{2} \mathrm{O}_{5} \rightarrow \mathrm{NaO} .3 \mathrm{~V}_{2} \mathrm{O}_{5}+\mathrm{SO}_{3} \\
\mathrm{Na}_{2} \mathrm{SO}_{4}+6 \mathrm{~V}_{2} \mathrm{O}_{5} \rightarrow \mathrm{Na}_{2} \mathrm{O} .6 \mathrm{~V}_{2} \mathrm{O}_{5}+\mathrm{SO}_{3}
\end{gathered}
$$

All are highly corrosion. Mixtures of these compounds can also exist further they can dissociate for example at the freezing point (Eq. 6):

$$
\mathrm{Na}_{2} \mathrm{O} .6 \mathrm{~V}_{2} \mathrm{O}_{6} \rightarrow \mathrm{Na}_{2} \mathrm{O} \cdot \mathrm{V}_{2} \mathrm{O}_{5} \cdot \mathrm{V}_{2} \mathrm{O}_{5}+\frac{1}{2} \mathrm{O}_{2}
$$

The effect of changing the ratio of sodium to vanadium of the corrosion. that, the mechanism of corrosion by vanadium involves (Eq. 7):

$$
\mathrm{Na}_{2} \mathrm{O} .6 \mathrm{~V}_{2} \mathrm{O}_{5}+\mathrm{Fe} \rightarrow \mathrm{Na}_{2} \mathrm{O} . \mathrm{V}_{2} \mathrm{O}_{4} \cdot 5 \mathrm{~V}_{2} \mathrm{O}_{5}+\mathrm{FeO}
$$

Weight loss in pipes of boilers: The weight loss measurement was used to calculate the mass loss of samples after each test, the specimen left to chill off step by step then cleaned to evacuate corrosion products by means of pickling arrangement Clarke's answer $(6 \mathrm{~g}$ methylamine $+500 \mathrm{~mL}$ refined water and hydrochloric corrosive to make $(1000 \mathrm{~mL})$ for $5 \mathrm{~min}$, this arrangement dosage not assault the metal but dissolves and remove the corrosion products films then the examples is washed by utilizing distilled water, benzene, acetone and alcohol then left the samples for $60 \mathrm{~min}$ to dry and afterward reweighted once more. The mass loss per unit area was using to obtain the following equation:

$$
\text { Corrosion Rate }=\Delta \text { W/A.t }
$$

Where:

$\Delta \mathrm{W}=$ Weight loss $=\mathrm{W}_{1}-\mathrm{W}_{2}(\mathrm{mg})$

A $=$ Surface area $\left(\mathrm{mm}^{2}\right)$

Effect of sulfur on contents: The three components of fuel principally in charge of erosion and stores (sulfur, vanadium and sodium), sulfur is the major offender and involved most frequently vanadium, troublesome as it is happens obviously just in some fuel oil while sodium is discovered all the more much of the time in fluid fuels sulfur is common to fuel oil and compounds of sulfur with iron. Oxygen and the alkalis are the most offenders in the wastage of metals and frequently in the accumulation of deposits (Rocca et al., 2003; Barbooti et al., 1988; Rapp, 1990; Rhys-Jones et al., 1983; Hancock, 1968, 1982; Khadom et al., 2009).

The importance of sulfur can be judged from the wide attention paid in the literature to the occurrence of its oxides in flue gases. Sulfur leads both to high temperature corrosion when complex sulfates are involved and to low temperature corrosion caused by $\mathrm{SO}_{3}$ condensation to form sulfuric acid. The sulfur content in fuel oil depends mainly on the source of the original crude. All petroleum curds contain sulfur, the amount of which can vary in the $(0.5-5 \%)$ range. Most of the sulfur in the petroleum occurs in organic compounds such as mercaptans, aliphatic sulfides, cyclic compounds, thiophene and polysulfides, Hydrogen sulfide and even elemental sulfur are also found in crude oil. During the distillation of crude oil, some of organic sulfur compounds decomposes and distribute in to the light products while the others like and elemental sulfur, hydrogen sulfide, mercaption and thiophenes tending to remain in the residual fuel oil. Generally, the sulfur content of petroleum fractions increases as the boiling ranger is higher (Laco et al., 2005; Phillips et al., 1961; Hameed et al., 2013; Sophia et al., 2012; Shukla et al., 2008).

Effect of sulfur trioxide: Explained the processes by which $\left(\mathrm{SO}_{3}\right)$ is formed in the flame and gas stream as flows, the sulfur in the oil will convert main to $\mathrm{SO}_{2}$ in the furnace (Eq. 8):

$$
\mathrm{S}+\mathrm{O}_{2} \rightarrow \mathrm{SO}_{2}
$$

Conversion of $\mathrm{SO}_{2}-\mathrm{SO}_{3}$ takes place in the furnace depending on fuel oil content, flame temperature and excess air his reaction is taking place if the temperature is sufficiently high for atomic oxygen to be formed by dissociation (Rhys-Jones et al., 1983; Hancock, 1968, 1982; Khadom et al., 2009; Young, 2008; Paul and Seeley, 1991 ) Eq. 9: 


$$
\begin{gathered}
\mathrm{O}_{2} \rightarrow 2 \mathrm{O} \text { (atom) } \\
\mathrm{SO}_{2}+\mathrm{O}(\text { atom }) \leftrightarrow \mathrm{SO}_{3}
\end{gathered}
$$

However, the reaction of $\mathrm{SO}_{2}$ with molecular oxygen is relatively slow even at high temperature. Theoretical equilibrium is not reached but in the presence of catalyst, this reaction is accelerated such catalysts are present in oil fired boiler deposits and the most active of these are Vanadium Pentoxide $\left(\mathrm{V}_{2} \mathrm{O}_{5}\right)$ and Iron Oxide $\left(\mathrm{Fe}_{2} \mathrm{O}_{3}\right)$. However, the conversion of $\mathrm{SO}_{2}$ to $\mathrm{SO}_{3}$ by catalytic action in the presence of catalysts is temperature dependent with high conversion in the range $(550-950)^{\circ} \mathrm{C}$, such temperature are available in the super heater zone (Saji and Thoumas, 2007; Shi, 2010; Voevodin et al., 2003; Otsuka, 2008; Kolpakov et al., 2007; Rout et al., 2003; Laco et al., 2005). In addition to the temperature dependence, the excess air level is also critical this catalytic formation of $\mathrm{SO}_{3}$ has been shown in practice to increase with boiler fouling, this is due partly to an increase in the deposits available and also the resultant increase in the temperature of deposits which reacts more favorable conditions for the reaction (Otsuka, 2008; Kolpakov et al., 2007; Voevodin et al., 2003; Rout et al., 2003; Laco et al., 2005; Phillips et al., 1961; Sophia et al., 2012; Hameed et al., 2013; Shukla et al., 2008). The ( $\left.\mathrm{SO}_{3}\right)$ has the effect of raising the acid dew point of gases which leads to corrosion and blockage at the low temperature zones. It also absorbed by carbon particles in the gas stream which results in the emission of acid smuts. The other undesirable effect is the visible chimney plum caused by sulfuric acid vapor condensation (Laco et al., 2005; Phillips et al., 1961; Sophia et al., 2012; Hameed et al., 2013; Shukla et al., 2008).

Effect of sodium contents: It is helpful to talk about the part of sulfur and sodium together, since it is compound $\left(\mathrm{Na}_{2} \mathrm{SO}_{4}\right)$ which is included in the hot corrosion reaction. The sodium in oil is primarily present as $(\mathrm{NaCl})$ and is promptly vaporized amid the burning procedure. There are various diverse systems by which vaporization can happen, yet once entire, the greater part of the sodium exist in the vapor stage as either $(\mathrm{NaOH})$ or $(\mathrm{NaCl})$, their relative extents being selected by interaction of the type (Hancock, 1968, 1982 ; Khadom et al., 2009; Young, 2008; Paul and Seeley, 1991; Srivastava et al., 1997; Saji and Thoumas, 2007; Shi, 2010; Voevodin et al., 2003; Otsuka, 2008; Kolpakov et al., 2007; Rout et al., 2003; Laco et al., 2005) Eq. 11 :

$$
\mathrm{H}_{2} \mathrm{O}+\mathrm{NaCl} \leftrightarrow \mathrm{NaOH}+\mathrm{HCl}
$$

$\mathrm{SO}_{3}$ in the flue gases will react with this $\mathrm{NaOH}$ to form $\mathrm{Na}_{2} \mathrm{SO}_{4}$ which will condense such as Eq. 12 :

$$
2 \mathrm{NaOH}+\mathrm{SO}_{4} \leftrightarrow \mathrm{Na}_{2} \mathrm{SO}_{4}+\mathrm{H}_{2} \mathrm{O}
$$

Sulfate formation becomes increasingly favorable thermos dynamically as the temperature decreases. The presence of sodium sulfate $\left(\mathrm{Na}_{2} \mathrm{SO}\right)_{4}$ increases the oxidation rat. Examined the possible manner of alloy sodium sulfate interaction. The suggested form in visitations, the following two stage mechanism to explain the complex nature of the observed reactions (Hameed et al., 2013; Shukla et al., 2008).

When the metal is in contact with the salt, tagger reaction occurs involving a Reducing $(R)$ which could by either the base metal or constituent of the alloy but could also be another reducing agent (e.g., carbon) Eq. 13:

$$
\mathrm{NaSO}_{4}+3 \mathrm{R} \rightarrow \mathrm{NaO}+3 \mathrm{RO}+\mathrm{S}
$$

This step is followed by metal sulfide formation Eq. 14:

$$
\mathrm{M}+\mathrm{S} \rightarrow \mathrm{MS}
$$

The second stage comprised (autocatalytic destruction) reactions (Eq. 15 and 16):

And:

$$
\mathrm{NaSO}_{4}+3 \mathrm{MS} \rightarrow 4 \mathrm{~S}+3 \mathrm{MO}+\mathrm{Na}_{2} \mathrm{O}
$$

$$
4 \mathrm{M}+4 \mathrm{~S} \rightarrow 4 \mathrm{M} \mathrm{S}
$$

Effect of vanadium contents: Vanadium is a particularly serious cause of external corrosion and its behavior is more complex it occurs in the oil as part of the pyrophyren molecules in which are probably $(\mathrm{VO})$ and $\left(\mathrm{VO}_{2}\right)$, both of which have been identified in the vapor phase their relative proportions being determined by the oxygen levels in the gas stream (Eq. 17):

$$
\mathrm{VO}+1 / 2 \mathrm{O}_{2} \rightarrow \mathrm{VO}_{2}
$$

As the fume is cooled $\left(\mathrm{VO}_{2}\right)$ is observed to form $\left(\mathrm{V}_{2} \mathrm{O}_{5}\right)$. Vanadium and sodium react to form products as low as $\left(540^{\circ} \mathrm{C}\right)$ with a eutectic of $\left(35\right.$ mole $\left.\% \mathrm{Na}_{2} \mathrm{O}\right)$ molten at $\left(350^{\circ} \mathrm{C}\right)$. The low melting compounds are the most harmful corrosives in residual fuels. Investigations indicated that three compounds were by reaction of sodium sulfate and vanadium pent oxide (Eq. 18-20):

$$
\begin{gathered}
\mathrm{Na}_{2} \mathrm{SO}_{4}+\mathrm{V}_{2} \mathrm{O}_{5} \rightarrow 2 \mathrm{NaVO}_{3}+\mathrm{SO}_{3} \\
\mathrm{NaSO}_{4}+3 \mathrm{~V}_{2} \mathrm{O}_{5} \rightarrow \mathrm{Na}_{2} \mathrm{O} .3 \mathrm{~V}_{2} \mathrm{O}_{5}+\mathrm{SO}_{3} \\
\mathrm{NaSO}_{4}+6 \mathrm{~V}_{2} \mathrm{O}_{5} \rightarrow \mathrm{Na}_{2} \mathrm{O} .6 \mathrm{~V}_{2} \mathrm{O}_{5}+\mathrm{SO}_{3}
\end{gathered}
$$


All are highly corrosives, mixtures of these compounds can also exist further they can dissociate for example, at the freezing point (Eq. 21):

$$
\mathrm{Na}_{2} \mathrm{O} .6 \mathrm{~V}_{2} \mathrm{O}_{5} \rightarrow \mathrm{Na}_{2} \mathrm{O} . \mathrm{V}_{2} \mathrm{O}_{4} .5 \mathrm{~V}_{2} \mathrm{O}_{5}+1 / 2 \mathrm{O}_{2}
$$

Three possible mechanisms have been described to explain how molten vanadium salts attack metal surface: Vanadate acts as oxygen carriers. Vanadate distorts the normal stable lattice of the oxide. Molten vanadate dissolves the normally protective oxide layer. The first mechanism was proposed by Small et al. Srivastava et al. (1997) who determined the effect of the change the ratio of sodium to vanadium of the corrosion of mnemonic 75 alloy at $\left(800^{\circ} \mathrm{C}\right)$. They concluded the mechanism of corrosion by vanadium involves (Eq. 22):

$$
\mathrm{Na}_{2} \mathrm{O} . \mathrm{V}_{2} \mathrm{O}_{5}+\mathrm{Fe} \rightarrow \mathrm{NaO} . \mathrm{V}_{2} \mathrm{O}_{4} \cdot 5 \mathrm{~V}_{2} \mathrm{O}_{5}+\mathrm{FeO}
$$

Hence, in this case, oxygen transfer occurred by the change in valence of the vanadium, leading to metal loss. The second mechanism was proposed by fair man which carried out crucible tests in a mixture of $(90 \%$ $\mathrm{V}_{2} \mathrm{O}_{5}+10 \% \mathrm{Na}_{2} \mathrm{SO}_{4}$ ). He concluded that oxygen atoms (or ions) were transferred to the metal surface by the vanadium. The mechanism of corrosion by vanadium is explained most satisfactorily by the catalytic action of $\left(\mathrm{V}_{2} \mathrm{O}_{5}\right)$ combined with an increase in the detect concentration of the scale. Khadom et al. (2009), Young (2008), Paul and Seeley (1991), Srivastava et al. (1997), Saji and Thoumas (2007), Shi (2010), Voevodin et al. (2003) and Otsuka (2008) concluded, the third mechanism best explains their observations. The experimental experiments showed the vanadium deposits were potentially corrosive to super heaters at a stream temperature of $\left(496^{\circ} \mathrm{C}\right)$, no

(a)

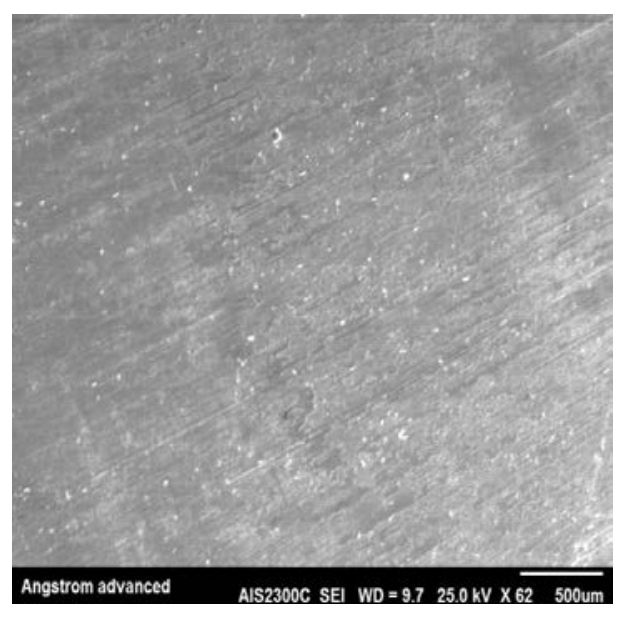

serious loss of metal occurred because no molten phase was present. When the metal temperature exceeded $\left(627^{\circ} \mathrm{C}\right)$ in laboratory tests, however, molten vanadium compounds were formed and the metal corroded.

It is evident that no consensus has been reached on the exact way in which vanadium causes external corrosion, however, a liquid phase is necessary for rapid loss of metal. The many possible compounds in which vanadium can occur on a surface complicate the situation. If there is any conclusion to be drown from the many investigations on vanadium it is element particularly in the presence of sodium and oxygen is almost certain to case wastage at metal temperature common to boiler plants (Young, 2008; Paul and Seeley, 1991; Srivastava et al., 1997; Saji and Thoumas, 2007; Shi, 2010; Voevodin et al., 2003; Otsuka, 2008; Kolpakov et al., 2007; Rout et al., 2003; Laco et al., 2005).

\section{RESULTS AND DISCUSSION}

Through visual analysis and practical experience show that the contaminates of fuel ash on the pipe surface causing corrosion in the pipes as well as fellow the water inside the pips of boiler containing a chloride, bicarbonate and sulphate where chloride has been known as aggressive ion cause the failure of these boilers as a result lead to stop boilers as well as economic loss to the country, the (Fig. 1a and b) represent of heavy fuel combustion residues sticking above the surface of the tube is the collateral damage caused waste. Figure 2 shows the Scanning Electron Microscopy (SEM) processr for carbon steel surface at ( 800 (without addition of ash) at different exposure times. Figure 3 shows of above process after test (with ash) at different exposure times. Figure 4-7 show the effect of time on weight loss (b)

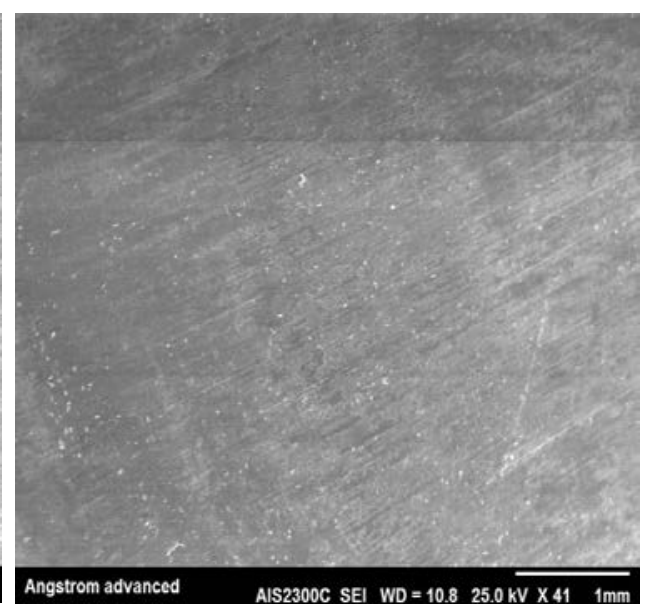

Fig. 2: Continue 
(c)

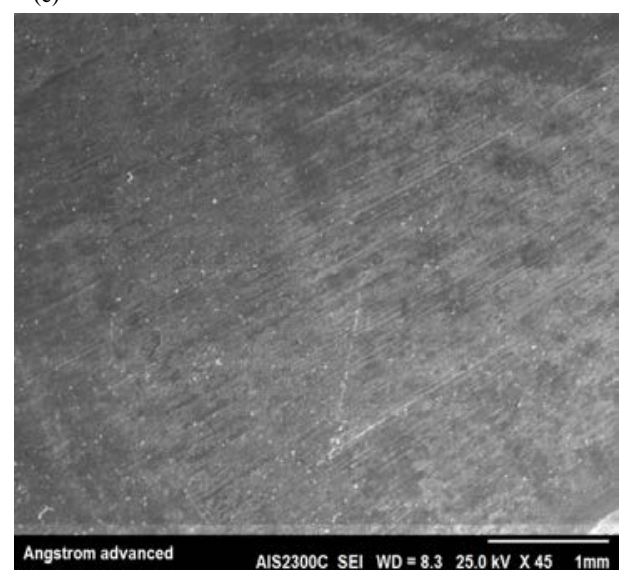

(d)

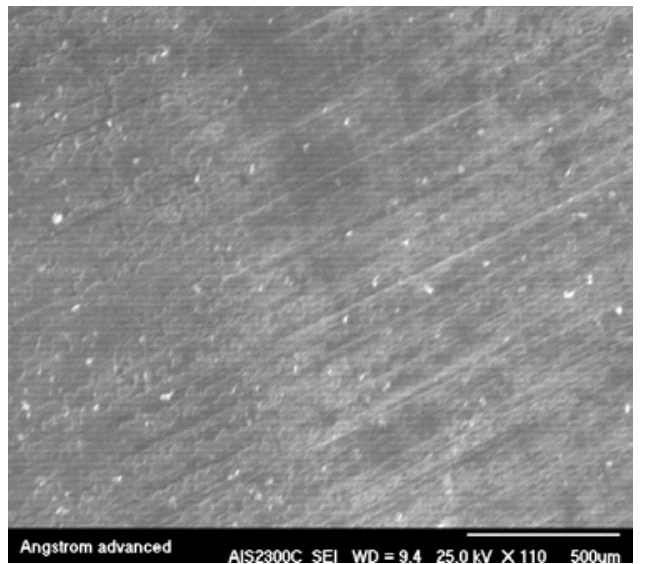

Fig. 2: Scanning electron microscopy for carbon steel surface at $8000 \mathrm{C}$ : a) Before exposure at $10 \mathrm{~h}$; b) Before exposure at $20 \mathrm{~h}$; c) Before exposure at $30 \mathrm{~h}$ and d) Before exposure at $40 \mathrm{~h}$ and the absence of ash

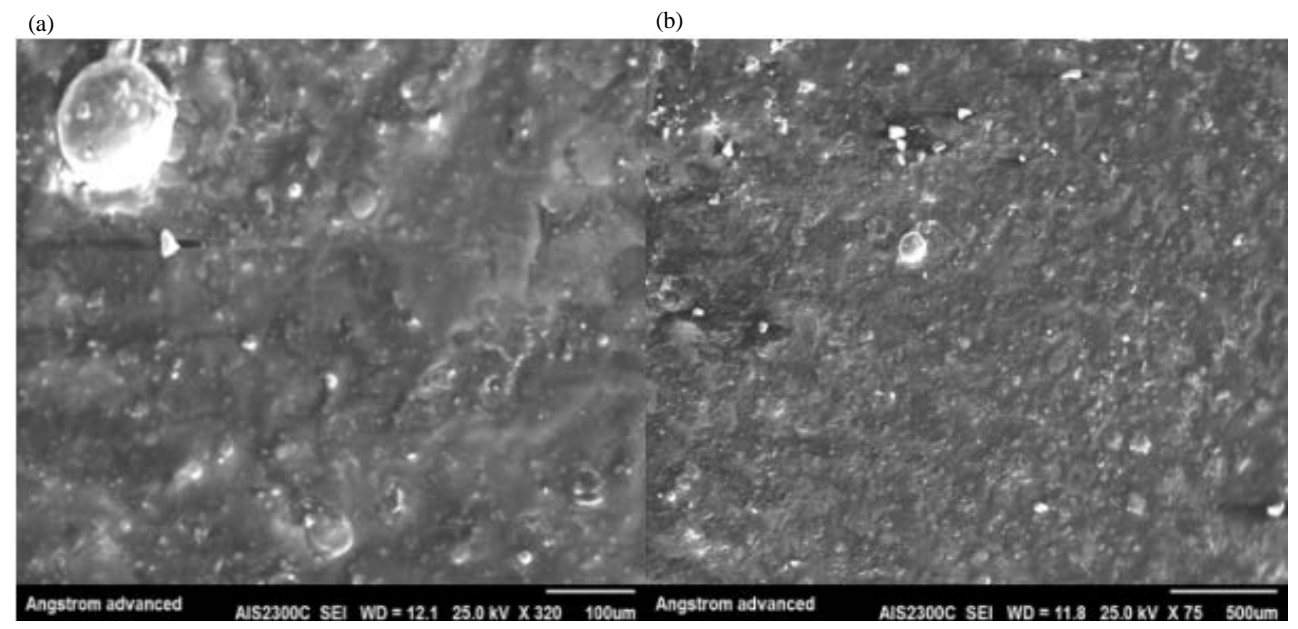

(c)

(d)

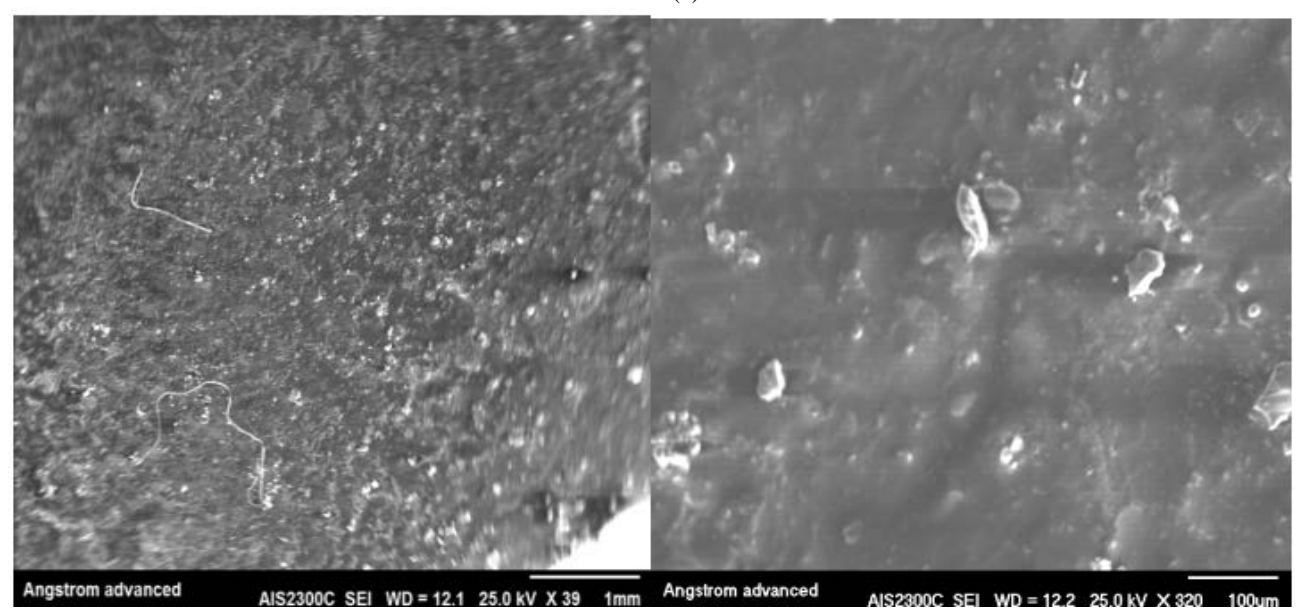

Fig. 3: Scanning electron microscopy for carbon steel surface at $8000 \mathrm{C}$ : a) After exposure at $10 \mathrm{~h}$; b) After exposure at $20 \mathrm{~h}$; c) After exposure at $30 \mathrm{~h}$ and d) After exposure at $40 \mathrm{~h}$ and the presence of ash 


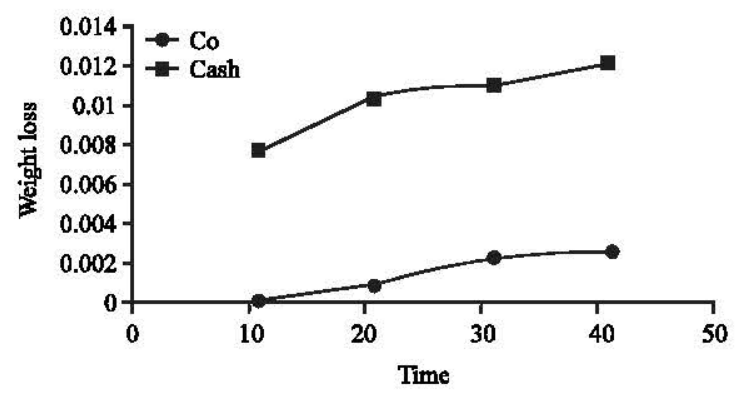

Fig. 4: The effect of time on weight loss at $\left(500^{\circ} \mathrm{C}\right)$ in presence and absence ash

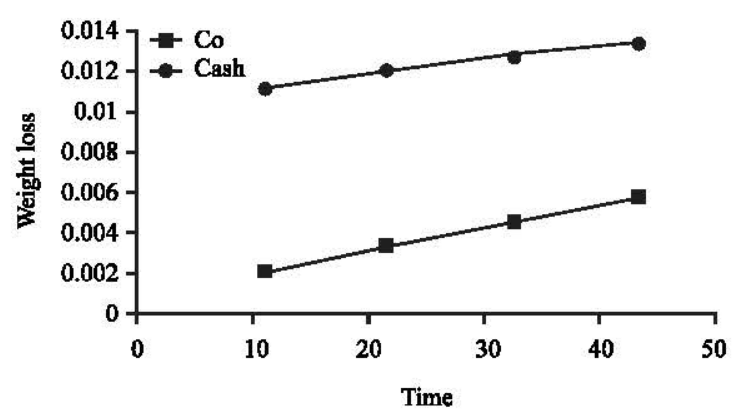

Fig. 5: The effect of time on weight loss at $\left(600^{\circ} \mathrm{C}\right)$ in presence and absence ash

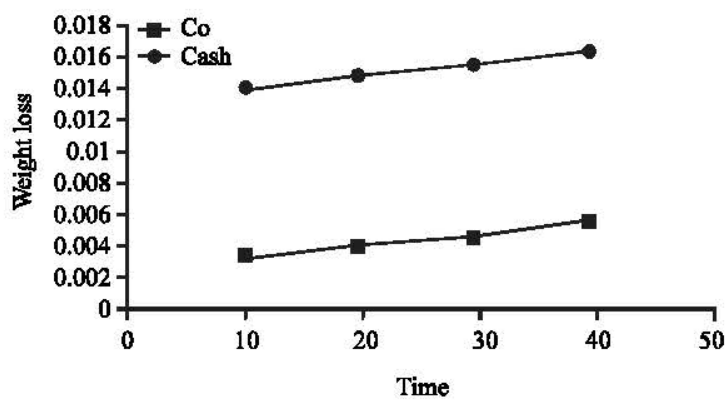

Fig. 6: The effect of time on weight loss at $\left(700^{\circ} \mathrm{C}\right)$ in presence and absence ash

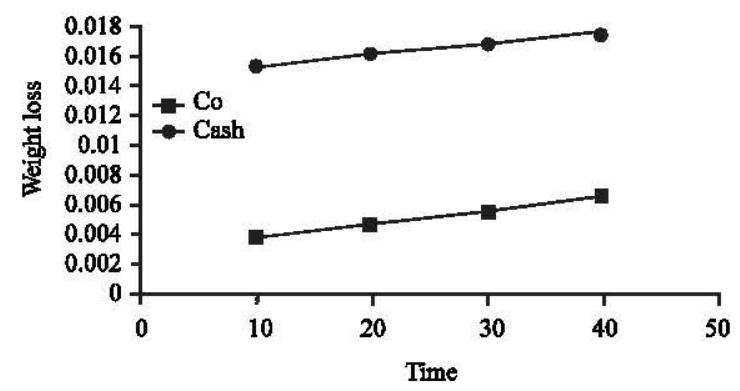

Fig. 7: The effect of time on weight loss at $\left(800^{\circ} \mathrm{C}\right)$ in presence and absence ash at different temperature. From these figures we note that increased temperature leads to increased weight loss in presence ash. This agreement with Young (2008).

\section{CONCLUSION}

The main reason of the external corrosion of pipes boiler is combustion of fuel inside the boiler generates ash. These wastes contain a high proportion of Sodium Sulfate $\left(\mathrm{NaSO}_{4}\right)$ and Vanadium $\left(\mathrm{V}_{2} \mathrm{O}_{5}\right)$ these compounds with a low melting point $(550-565)^{\circ} \mathrm{C}$. Attacking the surface of the tube leading to the outcome dissolution the metal.

The main reason of the internal corrosion. Flow induced corrosion seems to be the main cause Chloride $\left(\mathrm{Cl}^{-}\right)$, Bicarbonate $\left(\mathrm{HCO}^{3}\right)$ and Sulphate $\left(\mathrm{SO}_{4}\right)$ where Chloride $\left(\mathrm{Cl}^{-}\right)$has been known as aggressive in cause the failure of these boilers. The damage prevention options are suggested:

- First external corrosion, give inhibitor injection into oil like $\left(\mathrm{Al}_{2} \mathrm{O}_{3}, \mathrm{SiO}_{2}\right)$

- Second internal corrosion, make chemical treatment to water before used it in boiler

\section{ACKNOWLEDGEMENTS}

This research was supported by the National Natural Science Foundation of China (Project No. 51171067 , U1662114), the funding for basic business fees in central colleges and universities and the Foundation of Hubei Key Laboratory of Material Chemistry and Service Failure (No. 201502).

This research was financially supported by the innovation foundation of Huazhong University of Science and Technology Innovation Institute (No. 2015TS150, 2015ZZGH010). We acknowledge the support of the Analytical and Testing Center of the Huazhong University of Science and Technology for SEM measurements.

\section{REFERENCES}

Barbooti, M.M., S.A. Al-Niaimi and K.F. Al-Sultani, 2012. Dynamic studies on the inhibitive action of magnesium stearate on hot corrosion in a kerosene fired Furnace. J. Mater. Environ. Sci., 3: 686-697.

Barbooti, M.M., S.H. Al-Madfai and H.J. Nassouri, 1988. Thermochemical studies on hot ash corrosion of stainless steel 304 and inhibition by magnesium sulphate. Thermochimica Acta, 126: 43-49. 
Gouda, V.K., M.M. Nassrallah, S.M. Sayed and N.H. Gerges, 1981. Failure of boiler tubes in power plants. Br. Corros. J., 16: 25-31.

Hameed, R.A., A.A.H. Abu-Nawwas and H.A. Shehata, 2013. Nano-composite as corrosion inhibitors for steel alloys in different corrosive media. Adv. Appl. Sci. Res., 4: 126-129.

Hancock, P., 1968. Corrosion of Alloys at High Temperatures in Atmospheres Consisting of Fuel Combustion Products and Associated Impurities: A Critical Review. 1st Edn., HM Stationery Office, Richmond, UK.,

Hancock, P., 1982. The use of laboratory and rig tests to simulate gas turbine corrosion problems. Corros. Sci., 22: $51-65$.

Khadom, A.A., A.S. Yaro, A.A.H. Kadum, A.S. AlTaie and A.Y. Musa, 2009. The effect of temperature and acid concentration on corrosion of low carbon steel in hydrochloric acid media. Am. J. Applied Sci., 6: 1403-1409.

Kolpakov, S.V., V.A. Parshin and A.N. Chekhovoi, 2007. Nanotechnology in the metallurgy of steel. Steel Trans1., 37: 716-721.

Laco, J.I.I., F.C. Villota and F.L. Mestres, 2005. Corrosion protection of carbon steel with thermoplastic coatings and alkyd resins containing polyaniline as conductive polymer. Prog. Org. Coat., 52: 151-160.

Otsuka, N., 2008. A thermodynamic approach on vapor-condensation of corrosive salts from flue gas on boiler tubes in waste incinerators. Corros. Sci., 50 : 1627-1636.

Paul, L.D. and R.R. Seeley, 1991. Oil ash corrosion-A review of utility boiler experience. Corros., 47: 152-159.

Phillips, B., S. Somiya and A. Muan, 1961. Melting relations of Magnesium Oxide-Iron oxide mixtures in air. J. Am. Ceram. Soc., 44: 167-169.
Rapp, R.A., 1990. Hot corrosion of materials. Pure Appl. Chem., 62: 113-122.

Rhys-Jones, T.N., J.R. Nicholls and P. Hancock, 1983. Effects of $\mathrm{SO}_{2} / \mathrm{SO}_{2}$ on the efficiency with which $\mathrm{MgO}$ inhibits vanadic corrosion in residual fuel fired gas turbines. Corros. Sci., 23: 139-149.

Rocca, E., P. Steinmetz and M. Moliere, 2003. Revisiting the inhibition of vanadium-induced hot corrosion in gas turbines. J. Eng. Gas Turbines Power, 125: 664-669.

Rout, T.K., G. Jha, A.K. Singh, N. Bandyopadhyay and O.N. Mohanty, 2003. Development of conducting polyaniline coating: A novel approach to superior corrosion resistance. Surf. Coat. Technol., 167: 16-24.

Saji, V.S. and J. Thomas, 2007. Nanomaterials for corrosion control. Curr. Sci., 92: 51-55.

Shi, X., 2010. On the use of nanotechnology to manage steel corrosion. Recent Pat. Eng., 4: 44-50.

Shukla, S.K., M.A. Quraishi and R. Prakash, 2008. A self-doped conducting polymer polyanthranilic acid: An efficient corrosion inhibitor for mild steel in acidic solution. Corros. Sci., 50: 2867-2872.

Sophia, I.A., G. Gopu and C. Vedhi, 2012. Synthesis and characterization of poly anthranilic acid metal nanocomposites. Open J. Synth. Theory Appl., 1: 1-8.

Srivastava, S.C., K.M. Godiwalla and M.K. Banerjee, 1997. Fuel ash corrosion of boiler and superheater tubes. J. Mater. Sci., 32: 835-849.

Voevodin, N.N., V.N. Balbyshev, M. Khobaib and M.S. Donley, 2003. Nanostructured coatings approach for corrosion protection. Prog. Org. Coat., 47: 416-423.

Young, D.J., 2008. High Temperature Oxidation and Corrosion of Metals. Elsevier, Amsterdam, Netherlands, ISBN:9780080445878, Pages: 592. 